\title{
COVID-19 and California farm labor
}

\author{
COVID-19 may accelerate trends in California agriculture toward mechanization and the use of \\ guest-worker programs.
}

Philip Martin, Professor Emeritus, Department of Agricultural and Resource Economics, UC Davis

Online: https://doi.org/10.3733/ca.2020a0017

Many farmworkers already wear hairnets and gloves to enhance food safety, and in response to the COVID-19 pandemic, some employers have provided additional personal protective equipment.

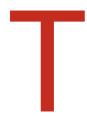

he stay-at-home orders issued in March to slow the spread of COVID-19 exempted essential farmworkers.

This article addresses three major questions: will there be enough farmworkers in California for the remainder of 2020, how can farmworkers be kept safe at work and home, and how will COVID-19 influence key long-term trends linked to farm labor, including rising wages and the growth of mechanization, migrant guest worker programs and imports of fresh produce?

Following the issuance of the stay-at-home orders in March 2020, most farm employers took immediate steps to avoid the introduction and spread of COVID-19. California's Division of Occupational Safety and Health (Cal/OSHA) required employers to update their Injury and Illness Prevention Programs to specify who is responsible for training employees about the virus, investigating illnesses and keeping records. Farm employers began to discourage sick employees from reporting to work, installed more handwashing facilities and implemented physical distancing while working and during breaks.

Many farmworkers already wear hairnets and gloves to enhance food safety, and some employers provided additional personal protective equipment. Transportation providers often made several trips with their buses and vans to allow riders to spread
out (Cimini 2020; Hecteman 2020). However, farmworker advo-
cates want employers to

do more to protect their employees.

\section{Peak-season farm employment}

Will there be enough farmworkers this summer, when California farm employment would ordinarily peak at almost 500,000?

As of early May, nearly two months into the COVID-19 closures, there have been more reports of farmers having to destroy commodities due to market disruptions than complaints of too few farmworkers.

Several factors will influence the availability of farmworkers in summer 2020, including the number of experienced farmworkers who get sick and cannot work. Many experienced farmworkers are not legally authorized to work in the United States and thus are ineligible for safety net benefits such as unemployment insurance, so they are likely to stay in or return to seasonal farm jobs. However, some workers may fall ill or stay home to care for sick family members or children whose schools and child care facilities are closed, reducing the availability of seasonal workers.

There is no absolute shortage of workers - more than 3 million Californians filed for unemployment benefits between mid-March and mid-April 2020 - but few unemployed nonfarm workers are likely to fill seasonal farm jobs. First, many are in cities and lack links to the labor contractors and crew bosses who match most farmworkers with jobs; they also would need to relocate to agricultural areas. Second, unemployment benefits may exceed agricultural earnings. A laid-off worker who had been earning $\$ 3,000$ a month would receive $\$ 350$ each week in unemployment benefits, plus $\$ 600$ each week in federal pandemic unemployment benefits through July 31,2020 , for total benefits of $\$ 950$ per week - substantially more than the $\$ 500$ per week average earnings of employees of farm labor contractors in 2018. 
All farmworkers, including those who are working in the United States illegally, are eligible for two weeks of paid sick leave of up to $\$ 511$ a day or $\$ 5,110$ in total if they were employed at least 30 days and are subject to quarantine orders due to COVID-19, or have been advised to self-quarantine by a health care provider or are experiencing COVID-19 symptoms. Farmworkers are eligible for two-thirds of their regular pay, up to $\$ 200$ a day or $\$ 2,000$ total, if they cannot work in order to care for someone with COVID-19 or a child whose child care facility or school is closed. Pending state legislation (AB 2915) would expand state-mandated paid sick leave, provide supplemental hazard pay to farmworkers and offer subsidies to those who care for the children of farmworkers. Some employers worry that the availability of these benefits will reduce the availability of seasonal workers.

\section{Farmworker safety}

In April 2020, meatpacking plants emerged as major COVID-19 hotspots, perhaps because they often have thousands of workers in close proximity in refrigerated environments that allow the virus to persist. After state and local governments closed several major plants, President Trump invoked the Defense Production Act to require them to reopen, albeit with improved protections for workers.

Farmworkers also work in close proximity, especially if they are following a conveyor belt in strawberry or lettuce fields to harvest commodities and place them on the belt. Rearranging crews so that some are in front and others behind the machine, or reducing crew sizes to allow physical distancing, can reduce the spread of the virus and productivity.

Limiting the spread of the virus in farmworker communities is another concern. Many farmworkers live in crowded housing; infections from a farm workplace could spread rapidly. Such workplace-originated COVID-19 clusters have not been found in California agriculture to date, but the meatpacking example demonstrates that the virus can spread quickly and reduce workforce availability. Public health officials and NGOs are supplementing employer efforts to educate farmworkers about COVID-19 and how to avoid being infected and transmitting the disease.

\section{Farm labor's changing role}

Longer term, COVID-19 is likely to join a list of factors - including the minimum wage rising toward $\$ 15$ an hour, and overtime pay after eight hours a day or 40 hours a week - that are raising labor costs and accelerating three major trends: labor-saving mechanization, more $\mathrm{H}-2 \mathrm{~A}$ guest workers and more imports of laborintensive commodities.

COVID-19 could spur renewed efforts to mechanize hand tasks in the medium term. Machines are being developed to harvest commodities that range from apples to melons, and growers are changing the layout of orchards and fields to facilitate mechanization. The "tipping point" when machines are cheaper than hand labor varies by commodity, but rising labor costs and declining machinery costs are accelerating the mechanization of canning peaches and raisin grapes.

The virus may further expand the $\mathrm{H}-2 \mathrm{~A}$ guest worker program that allows farmers who anticipate labor shortages to be certified to hire guest workers after they try and fail to recruit individuals who are working in the United States (either legally or illegally), and satisfy two other major conditions: provide free housing for guest workers and pay them the Adverse Effect Wage Rate of $\$ 14.77$ in 2020.

Because of the cost of housing and transportation in the metro counties with most labor-intensive commodities, $\mathrm{H}-2 \mathrm{~A}$ labor can cost farm employers as much as $\$ 24$ per hour, substantially more than the $\$ 15$ to $\$ 17$ per hour cost of U.S. farmworkers. Nonetheless, $\mathrm{H}-2 \mathrm{~A}$ workers have proven to be highly productive and California farm employers have been hiring them at increasing rates; the number of jobs certified to be filled with H-2A workers rose from 6,000 in FY15 to over 23,000 in FY19.

The final effect of COVID-19 could come via trade. California's agricultural exports are roughly $\$ 20$ billion annually. Rising wages or reduced availability of farmworkers could further shift the state's crop mix towards highly mechanized export-oriented crops like nuts and encourage the mechanization of hand harvested commodities. The United States currently imports half of its fresh fruit and a third of its fresh vegetables from Mexico, where farm labor costs are $10 \%$ of costs, mostly in California. Continued improvements in growing practices in Mexico are extending seasons and elevating quality, driving increased exports; for example, over half of the fresh tomatoes consumed in the United States today are imported from Mexico.

COVID-19 introduces new uncertainties for everyone. For California agriculture, COVID-19's major short-term challenge is to keep farmworkers and their families healthy, while in the longer term COVID-19 promises to accelerate trends that include faster mechanization, more guest workers and rising imports. CA

\section{References}

Cimini K. 2020. "'The perfect storm of vulnerability': Protection in the fields doesn't follow farmworkers home." The Salinas Californian, April 11. https://calmatters.org/california-divide/2020/04/farmworkers-coronavirus-outbreak-pandemic/

Hecteman K. 2020. Farms, facilities assure employee social distancing. AgAlert, April 1. www.agalert.com/story/?id=13870 